УДК: 72.036

ББК: 85.113

A43

DOI: $10.18688 / \mathrm{aa} 188-4-38$

Milan Prosen

\title{
The Evocation of the Russian Empire Style in Serbian Architecture
}

Buildings erected in Russian Neo-Empire style are the recognizable curiosity of great importance for the understanding of the development of the architectural heritage of Serbia and its diverse flows. They depict a specific epoch, when Russian national identity was clearly expressed in the Serbian environment. The Empire style evocations in Serbian architecture, primarily in Belgrade during the third and fourth decades of the $20^{\text {th }}$ century, concluded the evolution of its historical growth. The Empire style started as a branch of neoclassicism oriented towards motives of Roman imperial architecture; it was found suitable for the expression of Russian monumental architecture at the time of Emperor Alexander I in the period that followed his victory over Napoleon. This style marked one of the most fertile periods in the construction of St. Petersburg, seen on the monumental public buildings such as the Admiralty, the Stock Exchange, Mining Cadet Corps, The General Staff, Mikhailovsky Palace, Alexandrine Theater, Moscow triumphal gates, the Chamber of the Senate and Synod, the houses of Gagarin, Kukanova, and other notable families. Influenced by the $18^{\text {th }}$ century French culture, the Empire style underwent its evolution in the works of famous architects: Jean-François Thomas de Thomon, Andrean Zakharov, Andrey Voronikhin, Auguste Ricard de Montferrand, Carlo Rossi, Vasily Stasov, Osip Bove etc. [1].

Paraphrasing Roman architecture, the style of Alexander I adopted the elements of the Imperial Forum in Rome: the Triumphal Arch with a powerful, decorative crown stone and a coffered barrel vault, the use of classical columns, entablature, garlands, and classical motifs made of wrought iron. The selection and frequency of these motifs depended on the affinity of the author, both in the neoclassical period and in the $20^{\text {th }}$ century, when the style of Alexander I was reinterpreted in the epoch of the last Russian Emperor Nicholas II, emerging on representative buildings and residences such as the Ethnographic Museum in St. Petersburg, in 1911, or the Vtorov's house, in Moscow 1913-1915 [20].

At the time when the Empire style evolved, Serbian architecture started its development within the framework of the Balkan Oriental culture, gradually accepting cultural breakthroughs of Austro-Hungary with eclectic academism arriving from Vienna and Budapest. The change of the dynasty to the Serbian throne (1903) started the period of establishing strong political ties $^{1}$ and stronger permeation of Serbian culture and economy with the influences coming from Russia.

Prince Petar Karadjordjevic was brought to the throne in 1903 as the Serbian King Peter I. He educated 
Finding interest in the new Serbian market, St. Petersburg insurance company "Rossia" erected in Belgrade a representative palace with a café and a hotel "Moscow" [31] which was officially opened by King Petar I Karadjordjevic, in 1908 [8, pp.264-267]. The "Moscow" hotel was built in 1905-1907 according to the project of Pawel Karlovich Bergstresser, from St. Petersburg, who was the chief-architect of the insurance company "Rossia", in cooperation with the Belgrade architect Jovan Ilkić. It was not only one of the biggest edifices of the capital, but also a stylish curiosity that brought together the mixture of Viennese and Hungarian Art Nouveau and of the Russian Empire style. Elements of Art Nouveau are found in the fenestration and facade decoration made of majolica tiles, produced by the Zsolnay factory in Pécs - responsible for the embellishment of many Art Nouveau buildings in the Austro Hungarian Empire. The influence of the Russian Empire style appears with neoclassical friezes of garlands and a coffered arch motif with the accentuated crown stone, which appears as part of the allegorical figurative composition "The Glorification of Russia” which represents economic and naval forces of Russia (Ill. 51).

With the building of hotel "Moscow" in 1905, the motif of the arch with the accentuated crown stone taken from the Empire style of the epoch of Alexander I appeared in Serbian architecture and existed until the outbreak of World War II. This motif is found exclusively in the work of Russian immigrant architects. It was developed within the styles of the Academism, Art Deco, and Art Nouveau, on public and private buildings erected in Belgrade, the capital of the Kingdom of Serbia (1882-1918) and the Kingdom of Yugoslavia (SHS) (1918-1945).

Shortly after the opening of the prestigious "Moscow" hotel, Belgrade underwent tremendous destruction during World War I, which, like the very increase in population afterwards, turned the city into a busy construction site where Russian engineers and architects always had a guaranteed job [19]. Exceptional construction progress was also recorded in the city of Novi Sad, the center of the northern region of Vojvodina, in which a large number of immigrants found the new home.

Among the builders of Novi Sad very prominent was the architect Yuri Nikolaevich Schroeter, the nephew of the famous St. Petersburg architect Viktor Aleksandrovich Schroeter. Born in Odessa, he graduated from the St. Petersburg Institute of Civil Engineers of Emperor Nicholas I, and received the title of an independent architect. In Novi Sad, independently and in the cooperation with the architect Konstantin Petrovich Pariso de La Valette, Schroeter designed a series of private and public buildings, including the holders of neo-empire style: the Institute of the Public Health (1923) and the Officers' Club (1923-1926) [7]. The Institute of the Public Health, erected on the boulevard of the Queen Marija in 1923, evokes the monumental palace of the Senate and Synod in St. Petersburg, with a strengthened corner colonnade delivered in accordance with the possibilities and affinities of the new environment, integrated in the construction of modernized neo-empire style $[9$, p. 81; 23; 25; 30; 27, pp. 223-224]. Palace of the institute was decorated with classicist entablature and a decorative cartouche above the centrally positioned entrance, and painted in a yellow color with white accents (Fig. 1).

his two sons in St. Petersburg, and his daughter Jelena - sister of the future King Alexander I of Yugoslavia, in 1911 married Prince Ioann Konstantinovich Romanov. 


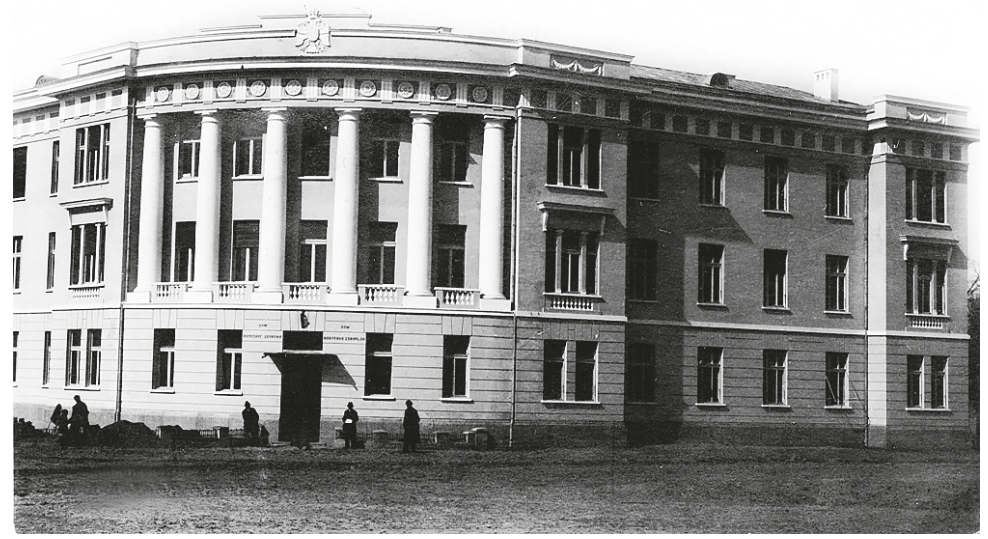

Fig. 1. Yu. N. Schroeter. The Institute of the Public Health, Novi Sad. 1923. Miloš Jurišić documentation

Like Schroeter, Yuri Pavlovich Kovaljevski, the architect of the Student Dormitory "King Alexander I" in Belgrade (1926-1928), had a model for the solemn representativeness of his design in the palaces of St. Petersburg built in the style of Alexander I. This dormitory in Belgrade was endowment of the Yugoslav king, Alexander I [27, p. 225], who laid the foundation stone on 9 May 1926 [2] by which "the poor students of the Belgrade University, <...> will get now, as the king's gift, an entire palace, with the comfort of a first-class hotel, one of the largest and most beautiful houses of the new Belgrade" [3] (Ill. 52).

Kovaljevski was born in Yelisavetgrad, educated at the Technical University in Kiev, and was a professor at the Polytechnic Institute to exile. Upon arrival in Belgrade in 1920, he worked as a city planner, and made the general urbanistic plan of Belgrade in 1923 [11]. Although Kovaljevski created a small number of objects in Serbia, the Student Dormitory of King Alexander I stands for one of the most representative palaces built in the third decade in Belgrade. Its monumental and eminent position among public buildings strongly emphasizes the presence of Neo-Empire in stylistic palette of Belgrade architecture. A great contribution to its representativeness is made by the effective motifs of Empire style, classical columns and garlands, highlighted with a bow and crown stone set with acanthus leaves, which like a crest adorned the tops of facade projections.

The Russian Empire Style was recognized as part of the unitary statehood style of Academicism, designed by Russian immigrant architects on a series of monumental buildings throughout the country [18, pp.350-353]. The typical motifs of the Empire style on some buildings, despite the lack of archival confirmations, were sometimes attributed to builders from cultural circles of the Russian emigration. This is the case with residential building in Belgrade's King Milan street No.8, where a two store upgrade was done in 1923 . The newly obtained second and third floors received a decorative frieze of garlands and torches, and facade was finished with tympanum niche with a coffered barrel vault, with an apex arch set with acanthus leaf [15]. 


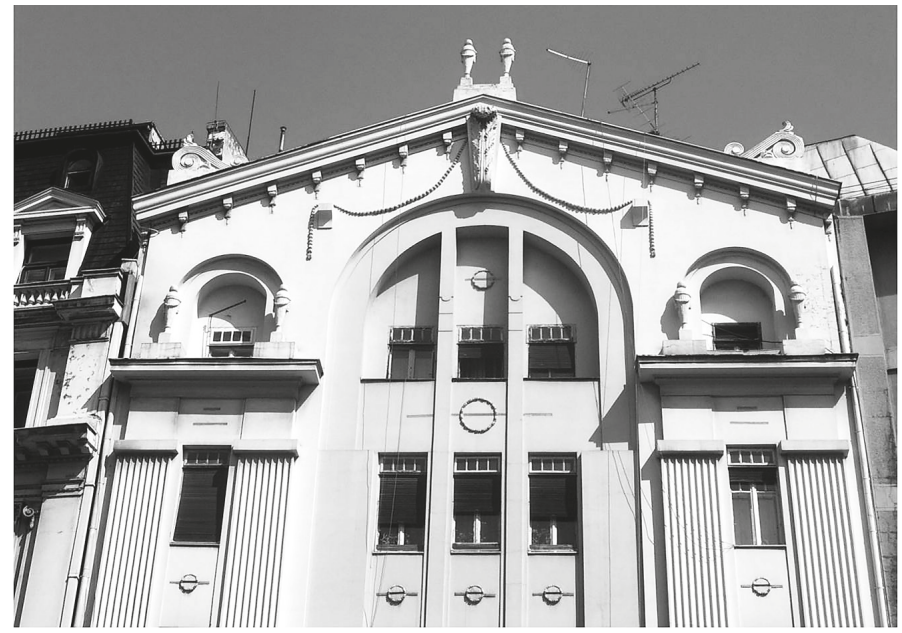

Fig. 2. R. N. Verhovskii, Knez Mihailova str., 34, Belgrade. 1922-1923. Milan Prosen documentation

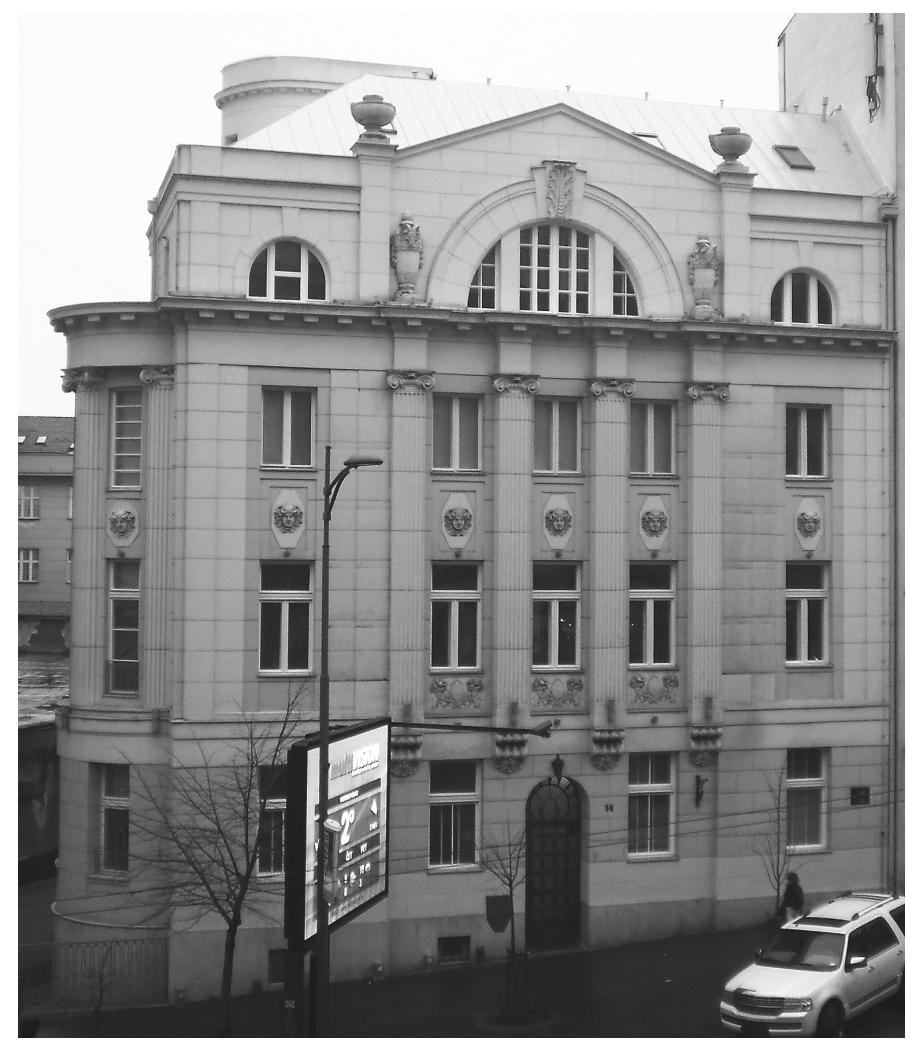

Fig. 3. N. P. Krasnov, Kneza Miloša str., 14, Belgrade. 1930. Milan Prosen documentation. 
The motif of a decorative arch with accentuated crown stone (often set with acanthus leaf) is found in the variety of interpretations on the edifices built by Russian architects. For residential commercial building in the prestigious main shopping street Knez Mihailova No. 34 (19221923) (Fig. 2), Roman Nikolayevich Verhovskii sets on top of the facade composition of the mentioned motive, decorated with long finely stylized garlands, volutes, and vases materialized with sophisticated delicacy of the Rococo and Art Nouveau styles [27, p.218]. Verhovskii graduated from the Imperial Academy of Arts in St. Petersburg. He came to Belgrade not only as an established artist, but also as a highly-decorated soldier [6, p.240; 16]. Employed with the Royal Palace Administration's and the Ministry of Construction of the Kingdom of SHS, Verhovskii was known as a versatile artist: architect, sculptor, and painter who exhibited his work as early as on the first exhibition of Russian artists organized in 1922.

When the Belgrade Architects and Engineers Association established the prize for the most beautiful facade, in the competition of the best works of Serbian authors, this first prestigious award for the period 1920-1923 was awarded to residential building erected in the street Svetozara Markovica, no. 65, built in 1921-1922 by the famous St. Petersburg architect, Nikolai Vasilyevich Vasilyev [21]. This builder, who during his biannual stay in Belgrade (May $1921-$ February 1923) [14], achieved a small but very significant oeuvre, in the discreetly expressed decorative part of the facade design comprised a modern interpretation of the motive of an arch and a keystone derived from the stylistic palette of the Empire style.

Some builders especially emphasized decorative treatment of a keystone: Nikolai Petrovich Krasnov on the residential building in Kneza Milosa street No. 14, erected in 1930 [8, p. 883] (Fig.3), Kovaljevski on the mentioned building of the Student dormitory as well as on the building of the kindergarten at Cara Dusana street built the same year [11, p. 175]. Some accentuated the arch itself: Verhovskii on the building intended for military officers' housing [29, p. 627] built near the palace of the General Staff, opens the façade with a monumental arch, paraphrasing the great arch of the General Staff in St. Petersburg. The same motif gives the architect Andrei Vasiljevich Papkov to the residential building in Višnjićeva street, developing the motif in a monumental version of Art Deco [28, p.317].

Among the interiors that evoke luxurious fame of St. Petersburg palaces, there was a Grand War Hall of the General Staff of the Kingdom of Yugoslavia [22] (Ill. 53) as one of the most important achievements of Russian artists in emigration, designed by architect Vasily Fedorovich von Baumgarten in 1928. He developed the design in monumental manner introducing sculpture and monumental columns on the facade, giving the interior spirit of luxury as a shining reflection of the State power. The Great War Hall is one of the most representative interiors in the interwar Belgrade, and the area where the restoration of the Russian Empire style pointed to historical Slavic heritage that took on the Kingdom of SHS created under King Aleksandar Karadjordjevic. Architect Vasily (Wilhelm) von Baumgarten was born in St. Petersburg, where he was educated at the Cadet Corpus of Alexander I, then Engineering College of Emperor Nicholas I and graduated from the High military engineering Academy of Nicholas I, where in the period of 1908-1914 he taught as an assistant professor, working also as an active designer in the city administration in St. Petersburg. Upon arrival to Belgrade he was employed in the Ministry of the Army and Navy as an architect with the rank of Major General [6, p. 231; 10;12;17]. 
In the presence of Yugoslav Queen Maria, Prince Paul, and Princess Olga, as well as the members of the Government of the Kingdom of Yugoslavia and numerous members of the Russian community in exile, Baumgarten, the five-year president of the Russian artistic association in Belgrade, held a speech which officially opened Russian House of Emperor Nicholas II on $9^{\text {th }}$ April 1933 [13; 26]. The Russian House was built after his design in 19311933. In addition to a foundation stone a founding Charter was laid, which testifies that the Russian House was created with the intention to be a treasure trove of cultural heritage, a place of scientific and artistic work and that "the Russian youth born in a foreign land receives education in the best traditions of the glorious Fatherland" [5].

A report in daily newspaper "Politika" gives the evidence of the reactions and the reception of the building of the Russian House by the Serbian public as well as among Russian emigres: "the Russian Empire style, which flourished during the Alexander II (Alexander I. - author's note), the imposing Palace of the House of Russian culture at Queen Natalia street, represents one exception in the architecture of Belgrade and means the entire experience for every cultural Russian immigrant who sees it. Indeed, in Russia, in this style countless buildings were erected, both in St. Petersburg and Moscow and throughout the countryside. All homes of the nobility and Russian landowners were erected in this style. However, for twelve years Russian immigrants did not have a chance to see anything similar. Nothing alike had been built in Russia since the revolution. Everything is simplified there now, and the architecture is all modern, without any decorations. So it appears that this is the only such building erected for so many years. $\langle\ldots\rangle$ This will be the center of overall Russian culture in exile; here all the numerous Russian cultural institutions that exist in Belgrade will be placed" [4].

The facade and interior of the building of the Russian House were designed in the Neo-Empire style, which paraphrases motifs of the Alexander I style. The ground floor is monumentalized by fluted Doric columns that carry classic entablature with alternating triglyphs and metopes. The fences of windows and balconies of the first floor are made of wrought iron with classic design, while on the fourth floor stand monumental arches decorated with accentuated cornerstone. The facade of the building received a bright yellow color, but all the elements of architectural ornamentation were carried out in white. In order to express the more majestic visual impact and monumentality of the style in a relatively narrow street, Baumgarten graded the form of the object in order to increase the surface and got the opportunity to develop a dynamic facade. The impression of power given by the rustic stone cladding of the base and columns is combined with elegant forms and fine ornamental decor that delicately develops to the height of the building (Fig. 4).

The Russian House housed schools, a library, a museum dedicated to Emperor Nicholas II, Russian scientific institute. It was used for concerts and theatrical performances of Russian artists. Due to the different purposes the interior was designed as a prominent representative public space decorated with pillars, arches, and coffered ceilings. The hall for meetings of the Russian community and a theater stage were designed in the shape of round exedras with columns evoking the Salon of Russian palaces of the late $18^{\text {th }}-$ early $19^{\text {th }}$ centuries. The walls of the ceremonial hall of the Russian House were decorated with relief frieze with classical motifs, the stage opened with monumental triumphal arch, in whose crown stone the figure of the goddess Thalia was placed. This sculptural decoration made in the style of Art Deco was a 
modernizing interpretation of the neoclassical motifs of Alexander I's Empire style. The Russian House in all mentioned parts of its architectural design and its artistic qualities stands out in the corpus the Neo-Empire style in Serbia. With its architecture and its strong pronounced messages, this historical monument becomes the keystone of the visual identity of Russian culture in emigration, an anthological example of this style and its last major achievement (Fig. 5).

Started in 1905 with the edifice of the "Moscow" Hotel in Belgrade, stylistic paraphrases and modifications of the Alexander I style occurred in Serbian architecture during three decades as one of the currents, present in a rich interweaving of styles strongly expressed in the period before the war occupation in 1941. The monuments of the Empire style are the part of oeuvre of Russian immigrant architects; they give visual identity for a particular cultural group, to which the restoration of this style had the importance of remembrance. As

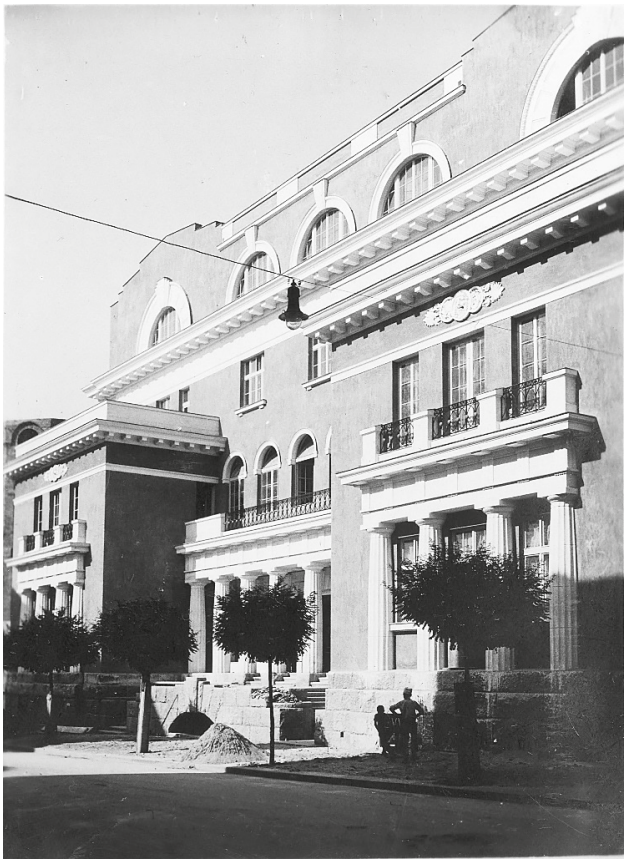

Fig. 4. V.F. fon Baumgarten. Russian Home of Emperor Nicholas II, Belgrade. 1933. Milan Sekulić documentation a final stage of the development of the inter-

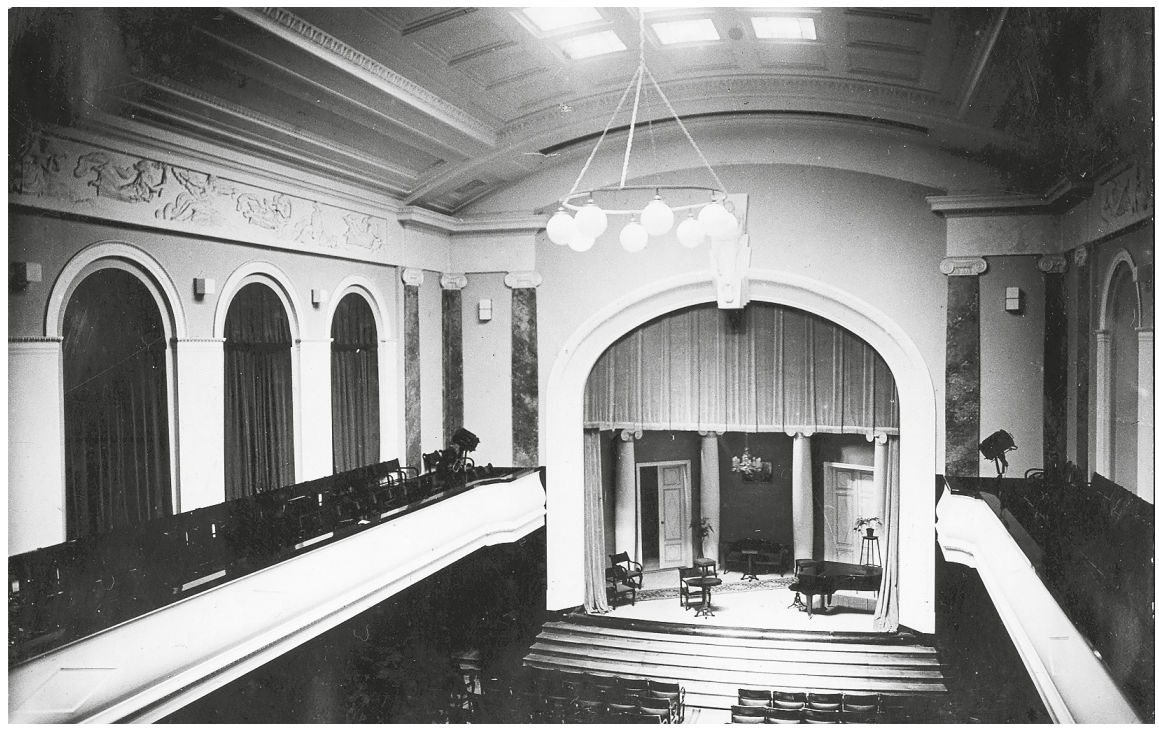

Fig. 5. V.F. fon Baumgarten, Ceremonial Hall of Russian Home, Belgrade. 1933. Milan Sekulić documentation 
national neoclassical style that developed on Serbian soil, the Neo-Empire style brought by Russian builders to Serbia became an art phenomenon significant both for Russian and Serbian culture, as well as for the world's architectural heritage.

\section{References}

1. Aleshina L.S. Leningrad i okrestnosti: Spravochnik-putevoditel' (Leningrad and Surroundings: Directory and Guide). Moscow; Leipzig, Iskusstvo Publ., 1980. 420 p. (in Russian).

2. Anonim. Osvecenje temelja Studentskog doma (The Consecration of the Foundations of the Student House). Politika. Belgrade, 29.04.1926 (in Serbian).

3. Anonim. Novi Studentski Dom (The New Student House). Politika. Belgrade, 9.05.1926. (in Serbian).

4. Anonim. U Beogradu živi oko 9 hiljada ruskih izbeglica (In Belgrade There Are about 9 Thousand Russian Refugees). Politika, 7.04.1933 (in Serbian).

5. Anonim. Russkii dom imeni Imperatora Nikolaia II v Belgrad (Russian House Named after Emperor Nicholas II in Belgrade). Belgrade, Russkii dom imeni Imperatora Nikolaia II Publ., 1933 (in Russian).

6. Arsenjev A. Biografski imenik ruskih emigranata. Ruska emigracija u srpskoj kulturi XX veka (Biographical Directory of Russian Immigrants. The Russian Emigration in the Serbian Culture of the $20^{\text {th }}$ Century). Belgrade Faculty of Philology, Department of Slavic Studies and the Center for Scientific Work Publ., 1994, p. 326 (in Serbian).

7. Arsenjev A. Petersburg architects of Novi-Sad: K. P. Parizo de la Valette and Y.N.Shreter. Izobrazitel'noe iskusstvo, arhitektura $i$ iskusstvovedenie Russkogo zarubezhiia (Investigation, Interpretation, Evaluation. Visual Arts and Architecture and Art Studies of Russian Abroad). Saint-Petersburg, Dmitrii Bulanin Publ., 2008, pp. 348-365 (in Russian).

8. Bogunović S. G. Arhitektonska enciklopedija Beograda XIX i XX veka I-III (Architectural Encyclopedia of Belgrade $19^{\text {th }}$ and $20^{\text {th }}$ Century, vols. 1-3). Belgrade, Beogradska knjiga Publ., 2005. 1517 p. (in Serbian).

9. Brdar V. Od Parisa do Brašovana, arhitektura javnih zdanja u Novom Sadu izmedju dva svetska rata (From Paris to Brashovan. Architecture of Public Buildings in Novi Sad between the Two World Wars). Novi Sad, Pavle Beljanski Memorial collection Publ., 2003. 120 p. (in Serbian).

10. Chuvakov V.N. Baumgarten Vasilii Fedorovich, von (October 30, 1879 - May 13, 1962, Buenos Aires.) Nezabytye mogily, Rossiiskoe zarubezhie: nekrologi 1917-1997. t.I (Unforgotten Graves, Russian Abroad: Obituaries 1917-1997, vol. I). Moscow, Pashkov Dom Publ., 1999, p. 228 (in Russian).

11. Đurđević M. Urbanističko-arhitektonska delatnost Đordja Pavloviča Kovaljevskog u Srbiji (Urbanistic Architectural Work of George Pavlovich Kovaljevsky in Serbia. The Belgrade City Annual, vol. 49-50. Belgrade, Belgrade City Museum Publ., 2002-2003, pp. 169-181 (in Serbian).

12. Đurđević M. Arhitekt Vasilij (Vilhelm) Fjodorovič Baumgarten (The Architect Vasily (Wilhelm) Fedorovich Baumgarten). The Belgrade City Annual, vol.51, Belgrade. Belgrade City Museum Publ., 2004, pp. 183190 (in Serbian).

13. Đurić O. Šezdeset godina Ruskog doma Imperatora Nikolaja II u Beogradu (1933-1993). Ruska emigracija u srpskoj kulturi XX veka (Sixty years of the Russian House of Emperor Nicholas II in Belgrade (1933-1993). The Russian Emigration in the Serbian Culture of the $20^{\text {th }}$ Century). Belgrade Faculty of Philology, Department of Slavic Studies and the Center for Scientific Work, Belgrade, Faculty of Philology, Department of Slavic Studies and Center for Scientific Research Publ., 1994, pp. 123-128 (in Serbian).

14. Jahontov A.; Prosen M. Stvaralaštvo arhitekte Nikolaja Vasiljeviča Vasiljeva i njegov beogradski opus (maj 1921. - februar 1923. godine) (The Work of the Architect Nikolaĭ Vasilyevich Vasilyev and his Belgrade Opus (May 1921. - February 1923)). Heritage 14. Belgrade, Belgrade Institute for Protection of Monuments of the City of Belgrade Publ., 2013, pp. 115-133 (in Serbian).

15. Jakovljević Z. Dva primera restauracije fasada (Two Examples of Facade Restoration). Heritage 1. Belgrade, Institute for Protection of Cultural Heritage Publ., 1997, pp.99-104 (in Serbian).

16. Kadijević A. Beogradski opus arhitekta Romana Nikolajeviča Verhovskoja (1920-1941) (The Belgrade Opus of the Architect Roman Nikolayevich Verhovskii (1920-1941)), Heritage 2, Belgrade. Institute for Protection of Cultural Heritage Publ., 1999, pp.33-40 (in Serbian).

17. Kadijević A. Baumgarten Vasilij (Vilhelm) Fjodorovič (Baumgarten Vasily (Wilhelm) Fedorovich). Serbian Biographic Dictionary. A-B. Novi Sad, Serbian Matica Publ., 2004, p. 446 (in Serbian). 
18. Kadijević A. Estetika arhitekture akademizma (19-20 vek) (Aesthetics Academicism Architecture (19 $9^{\text {th }}-20^{\text {th }}$ Centuries)). Belgrade, Builders book Publ., 2005, p. 488 (in Serbian).

19. Kadijević A. The Main Historical, Ideological and Esthetic Aspects of the Architecture of Russian Emigration in Yugoslavia 1920-1950 (Investigation, Interpretation, Evaluation). Izobrazitel'noe iskusstvo, arhitektura $i$ iskusstvovedenie Russkogo zarubezhiia (Visual Arts and Architecture and Art Studies of Russian Abroad). Saint-Petersburg, Dmitrii Bulanin Publ., 2008, pp. 325-336 (in Russian).

20. Kirikov B. M. Arhitektura Peterburga kontsa XIX - nachala XX veka. Eklektika. Modern. Neoklasitsizm (Architecture of Petersburg of Late $19^{\text {th }}-$ Beginning $20^{\text {th }}$ Centuries. Eclectics. Modern. Neoclassicism). SaintPetersburg, Kolo Publ., 2006. 447 p. (in Russian).

21. Lisovskii V. G.; Gasho R. M. Nikolay Vasilyev. Ot moderna k modernizmu (Nikolay Vasilyev. From Modern to Modernism). Saint-Petersburg. Kolo Publ., 2011. 463 p. (in Russian).

22. Marković S.; Videnović T.; Ibrajter-Gazibara B. Stari Generalštab (The Old General Staff Building). Belgrade, Institute for Protection of Cultural Heritage Publ., 2011 (in Serbian).

23. Mitrović V. Graditelji Novog Sada. druga polovina XIX i prva polovina XX veka (Builders of Novi Sad. Second Half of the $19^{\text {th }}$ and First Half of $20^{\text {th }}$ Century). DaNS 30. Novi Sad, 2000, p. 32 (in Serbian).

24. Mitrović V. Novosadski opus Konstantina Petroviča Parisa (Novi Sad Oeuvre of Konstantin Petrovich Paris). DaNS 40, Novi Sad, 2002, pp. 42-45 (in Serbian).

25. Mitrović V. Arhitektura XX veka u Vojvodini (The Architecture of $20^{\text {th }}$ Century in Vojvodina). Novi Sad, Academic book Publ., 2010, pp. 141-142 (in Serbian).

26. Prosen M. 75 godina Ruskog doma u Beogradu (75 years of Russian House in Belgrade). Heritage 9. Belgrade, Institute for Protection of Cultural Heritage Publ., 2008, pp. 211-220 (in Serbian).

27. Prosen M. Ruski arhitekti emigranti - arhitektura kao memorija (Russian Immigrant Architects Architecture as Memory). Spaces of Memory: Collection of Works. Vol.1, Architecture. A. Kadijevic; M. Popadic (eds.). Belgrade, Faculty of Philosophy Publ., 2013, pp. 213-230 (in Serbian).

28. Prosen M. Ar deko u srpskoj arhitekturi (Art Deco in Serbian Architecture), Ph.D. Dissertation. Belgrade, Faculty of Philosophy, 2014. 630 p. (in Serbian).

29. Prosen M. The Participation of Russian Architects and Sculptors in Making Art Deco Architecture in Serbia. Actual Problems of Theory and History of Art: Collection of articles, vol. 6. A. V.Zakharova, S. V. Maltseva, E. Yu. Stanyukovich-Denisova (eds.). Saint-Petersburg, NP-Print Publ., 2016, pp.624-634. Available at: http://dx.doi.org/10.18688/aa166-8-67 (accessed 1 February 2017).

30. Stančić D. Novi Sad od kuće do kuće (Novi Sad from House to House). Novi Sad, Institute for the Protection of Cultural Monuments of the City of Novi Sad Publ., 2005, pp. 372-375 (in Serbian).

31. The Catalogue of Cultural properties in Belgrade. Institute for Protection of Cultural Heritage. Available at http://beogradskonasledje.rs/kd/zavod/stari_grad/zgrada_hotela_moskva.html (accessed 1 February 2017) (in Serbian and in English)

Title. The Evocation of the Russian Empire Style in Serbian Architecture.

Author. Milan Prosen - Ph.D., assistant professor. University of Arts in Belgrade, Kralja Petra 4, 11000 Belgrade, Serbia.milan.prosen@fpu.bg.ac.rs; milanprosen@gmail.com

Abstract. This paper aims to highlight the acceptance of the Russian Empire style in the first half of the $20^{\text {th }}$ century in Belgrade. The occurrence of the Empire style in Belgrade is unusual in relation to the time and spatial distance and the fact that the style was not present in Serbian cultural environment in the period of its flourishing during $19^{\text {th }}$ century. The elements of the Empire style in public and private buildings are the evocation of the cultural memory of the Russian Empire, which was abolished at the time of the formation of capital of the Kingdom of SHS.

This paper presents the research of the activities of Russian architects in Belgrade as a reflection of architectural, cultural, and political ties of St. Petersburg and the capital of the newly formed Kingdom of SHS/ Yugoslavia. The work traces the development of the architecture of Belgrade through the work of prominent emigrant builders, who arrived mainly from St. Petersburg, and who despite adaptation to already established stylistic currents in Belgrade, strongly emphasized their national diversity, evoking the imperial style of Alexander I that marked $19^{\text {th }}$-century buildings of Russian capital. The buildings erected in the Russian Empire style are rare for the Serbian environment. The significance of this architectural heritage is that it reflects an era and clearly stated Russian national identity, analogous to the representative buildings erected in St. Petersburg and Moscow in the $19^{\text {th }}$ century. The evocation of the Russian Empire in Belgrade in the period 1920-1933 is 
also the last emanation of this style, which makes this phenomenon very important both for Russian and Serbian culture and also significant in the wider context of the world's architectural heritage.

Keywords: Russian emigrant architects; Neo-Empire style; Empire style; Russian architecture; Serbian architecture in the 1920s and 1930s.

Название статьи. Отголоски русского стиля ампир в сербской архитектуре.

Сведения об авторе. Просен Милан - Ph.D., доцент. Университет искусств, ул. Краля Петра 4, Белград, Сербия, 11000. milan.prosen@fpu.bg.ac.rs; milanprosen@gmail.com

Аннотация. Статья призвана осветить рецепцию русского ампира в архитектуре Белграде первой половине XX в. Возникновение стиля ампир в Белграде необычно по удаленности по времени и расстоянию, а также и потому, что этот стиль не присутствовал в культуре Сербии в XIX в., в период своего расцвета в Европе. Элементы стиля ампир в общественных и частных зданиях - это пробуждение культурной памяти о Российской империи, крах которой по времени совпал с оформлением столицы Королевства Сербов, Хорватов и Словенцев (СХС).

Статья представляет результаты исследования деятельности русских архитекторов в Белграде как отражение архитектурных, культурных и политических связей Санкт-Петербурга и столицы новообразованного Королевства СХС/ Югославии. Прослеживается развитие архитектуры Белграда через творчество строителей-эмигрантов, которые прибывали в основном из Санкт-Петербурга и которым, несмотря на включение в уже сложившиеся стилистические течения в Белграде, удалось подчеркнуть свое национальное многообразие, в том числе обращаясь к ампиру Александра I, характерному для российской столицы XIX века. Здания, построенные в стиле русского ампира, являются редкостью в сербской среде. Значимость этого архитектурного наследия заключается в том, что оно отражает эпоху и четко заявляет о русской национальной идентичности, аналогично представительным зданиям, построенным в Петербурге и Москве в XIX в. Возрождение идей русского ампира в Белграде в 1920-1933 гг. стало последней эманацией этого стиля, что делает это явление чрезвычайно важным для русской и сербской культуры, и в более широком контексте - мирового архитектурного наследия в мире.

Ключевые слова: русские архитекторы-эмигранты, неоампир, ампир, русская архитектура, сербская архитектура 1920-х и 1930-х годов. 

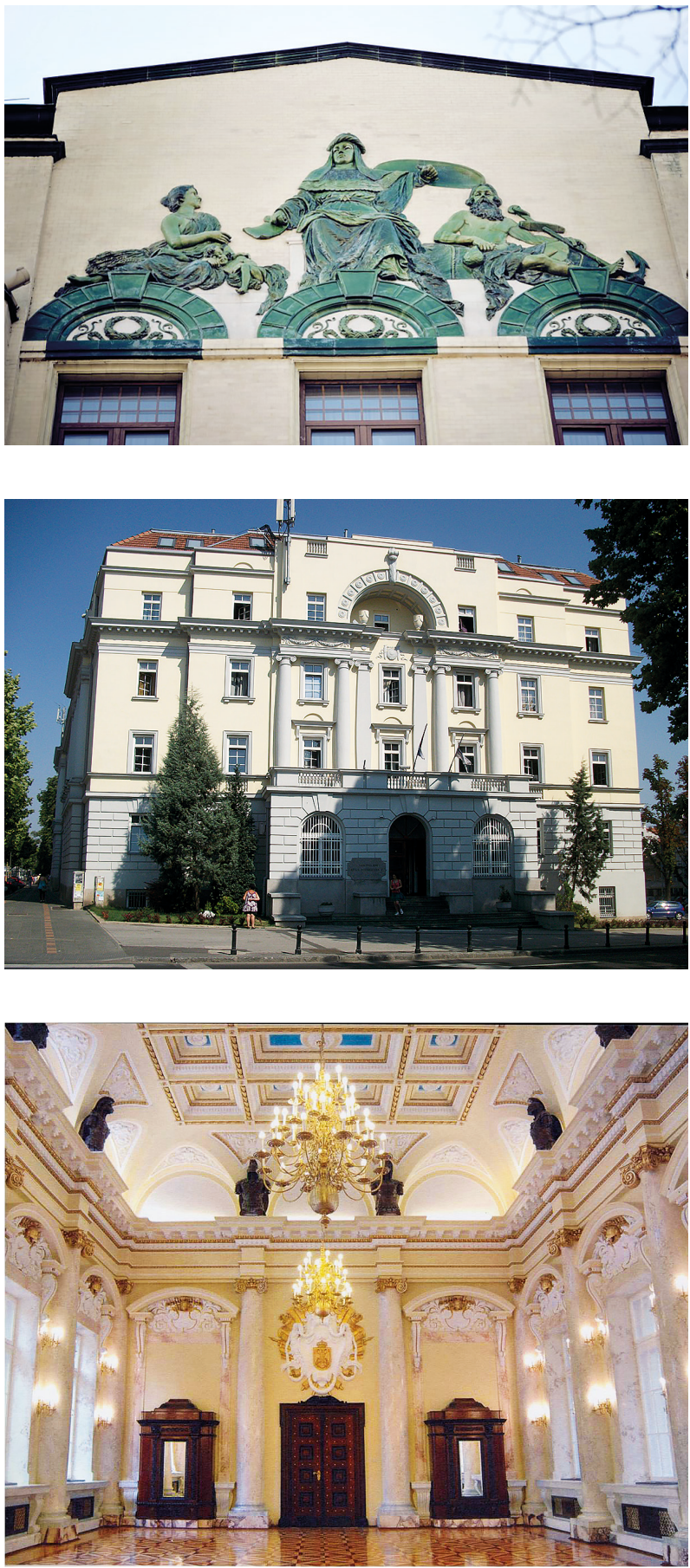

Ill. 51. P. K. Bergstresser, J. Ilkić. Hotel "Moscow", Belgrade. 1905-1907. Relief "Glorification of Russia”. Milan Prosen documentation

Ill. 52. Yu. P. Kovaljevski, Student Dormitory “King Alexander I", Belgrade. 1926-1928.

Milan Prosen documentation

Ill. 53. V.F.von Baumgarten. The Ceremonial hall of the General Army and Navy headquarters of the Kingdom of Yugoslavia, Belgrade. 1928. Milan Prosen documentation 